\title{
ON THE PHENOMENOLOGICAL STRUCTURE OF ETHICAL TESTIMONY
}

\section{NICOLAS GARRERA-TOLBERT}

PNPD/CAPES post-doctoral researcher at the Department of Philosophy, Pontifical Catholic University of Paraná, 80215-901 Curitiba, Brazil.

E-mail: nicolasgarrera@gmail.com

The essay aims to elucidate the phenomenological structure of ethical testimony. I start by referring to the perplexing current situation that, despite our having a plurality of testimonies that elaborate, often in a philosophically insightful manner, the experience of those whose lives were transfigured by the emergence of human evil, philosophy has not yet undertaken a systematic investigation of the philosophical and, especially, ethical significance of testimonies. Further, I present a concept of testimony as a proto-philosophical, narrative elaboration of the meaning of "ethical experience». I define the latter as an experience in which the irreducibility of good to evil («ethical difference») is revealed to us as «evidence» that cannot be denied, except perhaps at the price of betraying ourselves in our innermost self or identity $(\S 1)$. Second, I show why phenomenology has a crucial role to play in the elucidation of the philosophical meaning of testimony and describe in some detail the relationship between ethical experience and testimony. In particular, I examine the crucial issue of the impossibility of exhausting the meaning of ethical difference in a purely theoretical or conceptual discourse: ethical difference, I claim, is not a pure eidos, but is always given in experience as an un-totalizable plurality of meanings, as a radically open series of expressions of the cleavage between good and evil as an irreducible polarity ( $(2)$. Finally, I suggest that Heidegger's analysis of «testimony» (Bezeugung) in $\S 54-60$ of Sein und Zeit may be read as describing some essential traits of our encounter with truth(s) as given in experience. On this basis I briefly show that, when interpreted in specifically ethical terms, such an analysis may contribute to the understanding of how ethical difference is actually given in experience, and, consequently, of testimony in its ethical dimension (§ 3$)$.

Key words: ethical call/demand (appel/Anruf), ethical difference, ethical experience, evidence, testimony, Heidegger.

(C) Nicolas Garrera-Tolbert 


\section{О ФЕНОМЕНОЛОГИЧЕСКОЙ СТРУКТУРЕ ЭТИЧЕСКОГО СВИДЕТЕЛЬСТВА}

\section{НИКОЛАС ГАРРЕРА-ТОЛБЕРТ}

Исследователь-постдокторант (PNPD/CAPES) в Папском католическом университете Параны, 80215-901 Куритиба, Бразилия.

E-mail: nicolasgarrera@gmail.com

Это статья направлена на прояснение феноменологической структуры этического свидетельства. Я начинаю с указания на сложность сложившейся ситуации: несмотря на множество свидетельств, часто философски насыщенным образом описывающих опыт тех, чьи жизни были изуродованы вмешательством человеческого зла, философия до сих пор не предприняла систематического исследования философской и, в особенности, этической значимости свидетельств. Затем я представляю понятие свидетельства как прото-философское, наративное развертывание значения «этического опыта». Я определяю последний как опыт, в котором несводимость добра ко злу («этическое различие») проявляется для нас в качестве «очевидности», которую невозможно отрицать, пожалуй, за исключением случаев предательства нами нашей самой глубинной самости или идентичности (§ 1). На следующем этапе я показываю, почему феноменология должна сыграть ключевую роль в прояснении философского значения свидетельства и описываю в деталях взаимосвязь этического опыта и свидетельства. В частности, я рассматриваю ключевую проблему невозможности исчерпывающего выражения этического различия в чисто теоретическом или концептуальном опыте: я утверждаю, что этическое различие - это не чистый эйдос, напротив, он всегда дан в опыте как нетотализируемая множественность значений, как радикально открытые серии выражений раскола, пролегающего между добром и злом (как между двумя несводимыми друг к другу полюсами) (§ 2). Наконец, я предполагаю, что хайдеггеровский анализ свидетельства (Bezeugung) в § 54-60 «Бытия и времени» можно прочесть как описание сущностных черт нашей встречи с истиной (истинами), которая может быть дана нам в опыте. На этом основании я кратко демонстрирую то, как такой анализ, проинтерпретированный в специфически этических терминах, может внести свой вклад в понимание того, как этическое различие действительно дано в опыте, и, следовательно, в понимание свидетельства в его этическом измерении (§3).

Ключевые слова: этический зов (appel/Anruf), этическое различие, этический опыт, очевидность, свидетельство, Хайдеггер.

There is now a wide consensus among genocide scholars, as well as critical theorists and philosophers working on mass violence phenomena, that survivors' testimonies can contribute significantly to understanding these kinds of events in all their complexity. Moreover, there can be no doubt that some testimonies have immense philosophical value. As Levi and Rothberg write, «whatever the problems of memory and point of view that such documents [the writings of first-hand witnesses, survivors of the Shoah] exhibit, they offer an unparalleled access to the $<\ldots>$ subjective experience of catastrophe. 
We would go even farther and assert that some survivor testimony engages in precisely the kind of self-reflective, critical meditation that we call theory» (Levin \& Rothberg, 2003, 25). One need only think, for instance, of the testimonies of Primo Levi (1989 \& 1991), David Rousset (1981 \& 2010), Robert Antelme (1999), Jorge Semprún (1994), Jean Améry (1966), and Claude Lanzmann (1984). Although these testimonies of survivors of the Shoah are well-known, ${ }^{1}$ the thesis I will be defending about the nature or truth of testimonies is not restricted to them. In fact, a philosophical study of testimony cannot be limited to the examination of particular testimonies of the survivors of the Shoah or other genocides: ${ }^{2}$ to clarify the phenomenon of testimony as a singular domain of meaning, such a study must delineate a concept of testimony. In other words, it is imperative both to respect each testimony in its singularity and to understand what it is that makes of the very existence of the plurality of testimonies a philosophically relevant phenomenon.

This essay outlines of an account of testimony that conceives of it as an elaboration of a specific kind of experience that only occasionally takes the form of a properly traumatic experience of radical and generalized evil, as in the case of the survivors of genocides. However, the most philosophically challenging and insightful testimonies are those that emerged from the survivors' experience of having been exposed to an evil that, almost unimaginably, became the norm. Despite the fact that many of these testimonies are well-known, philosophy has not yet undertaken a systematic investigation of the philosophical meaning of testimonies, and, in particular, its ethical relevance. The essay aims to show why testimony matters to ethics, i.e., what we ethical theorists should learn from the very existence of the factual plurality of testimonies. Specifically, I will be

\footnotetext{
1 Sometimes the Shoah is interpreted as the very paradigm of genocide (if not evil tout court); however, my account of testimony does not require the reader to agree with this view. Moreover, (s)he should bear in mind that my analyses do not assume that the Shoah has a unique character, be it on the historical, metaphysical, theological, or ethical level. (For the issue of the alleged uniqueness of the Shoah, see Rosenbaum (2009), Levene (1988), and Katz (1994). The latter is an attempt to establish the Shoah's uniqueness on historical grounds).

2 Broadly construed, genocides can be described as cases of extreme, generalized political violence involving serious criminal and immoral acts committed against particular groups of people that have been targeted for extermination. For the purposes of this essay, it suffices to bear in mind the legal definition of genocide as adopted in 1948 by the Convention on the Prevention and Punishment of Genocide: «Any of the following acts committed with intent to destroy, in whole or in part, a national, ethnical, racial or religious group, as such: a) Killing members of the group; b) Causing serious bodily or mental harm to members of the group; c) Deliberately inflicting on the group conditions of life calculated to bring about its physical destruction in whole or in part; d) Imposing measures intended to prevent births within the group; e) Forcibly transferring children of the group to another group» (as cited in May 2004, 4). Curthoys \& Docker (2008) offer an in-depth analysis of the concept of genocide in their Defining Genocide. For the concept of genocide see also Levine (2005), esp. pp. 35-89. Obviously, the study of genocide so construed has many dimensions. As it will become clearer later, a phenomenologicallyoriented ethics of testimony is primordially interested in giving an account of the experience of a subjectivity that becomes traumatically affected by the emergence of radical evil.
} 
focusing on the issue of the «object» or «truth» (hereafter only «truth») of testimony. In the discussion of this topic I will briefly examine an important development in the «philosophies of testimony»: § 54-60 of Heidegger's «Sein und Zeit». ${ }^{3}$ At first sight, this choice might seem awkward. In effect, Heidegger's analyses aim to interpret the phenomenon of «attestation» or «testimony» (Bezeugung) in strictly ontological — not ethical - terms. However, despite his deliberate refusal to think of testimony without recurring to the fundamental polarity good/evil as an irreducible ethical difference, Heidegger's analysis is still relevant for a phenomenologically-oriented ethics of testimony because it elucidates important aspects of the transcendental structure of the truth of attestation. Before addressing this issue let me clarify in a broad manner why I think phenomenology must play a major role in the examination of testimony.

The concept of testimony I defend in this essay is inextricably related to a specific kind of experience: ethical experience. This is the singular kind of experience in which the irreducibility of good to evil (or «ethical difference») is revealed to us as «evidence» that cannot be denied, except perhaps at the price of betraying ourselves in our innermost self or identity, i.e., radically violating our fundamental sense of integrity. ${ }^{4}$ In other words, in ethical experience each of us is confronted by the (moral) impossibility of living one's life in denial of the very reality of ethical difference. It is the meaning of this kind of experience that testimonies attempt to elaborate. In this sense, each testimony is a meditation on the transfiguration of a life by the emergence of ethical difference.

I claimed that the truth of testimony is ethical difference, i. e., the experiential givenness of the difference between good and evil as an irreducible «Faktum». This is a first-personal, eminently affective, and often traumatic kind of experience. The testimonies previously mentioned are eminent expressions of ethical experience so construed:

3 (Heidegger, 1967). Other important philosophical texts on testimony are (Levinas, 1972) and its rewriting in (Levinas, 1974, § 5.2), «La gloire de l'infini»; Ricoeur, 1994a, 1994b; Nabert, 1996, 263-380, esp. book III, «Métaphysique du témoignange et herméneutique de l'absolu»; Derrida, 1996; Derrida, 2005; Ricoeur, 2000, 201-208; Agamben, 1998.

4 In the ethical domain, identity must be conceived in narrative terms. For a clear, brief account of narrative identity see (Ricoeur, 1988). In order to clarify the notion of integrity a careful analysis would be needed. In the context of our discussion, though, it suffices to observe that «integrity» describes the fact of being aware of one's being «destined» to responsibility and knowing that one is capable of inscribing this responsibility into the world, i. e., exercising one's freedom to fulfill the demands of responsibility. I use the term «integrity» and not «dignity» because I am not referring to an essential trait of human beings, but to a quality of one's experiences or an aspect of one's subjective position (regarding oneself and others) emerging out of our ultimately contingent encounter with ethical difference; as such, and contrary to the dignity of persons, integrity may be taken away by contingent circumstances of all sorts (historical, political, and so on). 
in a narrative form, they offer an account of the very taking place of human evil in its most extreme manifestation - and therefore also of «good», even if only glimpsed as the absence or ending of that evil. Rather than trying to prove the existence of testimonies in the sense previously characterized, ${ }^{5} \mathrm{I}$ will show that the "space of meaning» opened by ethical experience somehow requires those narratives we usually call «testimonies» as a way of finding their expression in discourse.

If it is true that a testimony is an eminent expression, a «pre-» or «proto-philosophical» elaboration of ethical experience, then it becomes clear why phenomenology is the necessary approach in the philosophical elucidation of testimony: phenomenology is a form of philosophical inquiry equipped to examine the meaning of experience without imposing to it pre-conceived conceptual schemes. In so doing, phenomenology respects the phenomenality of experience, i. e., its irreducible character. In «La phénoménalité de Dieu», Jean-Yves Lacoste $(1998,78)$ writes, «...if it is $<\ldots$. good phenomenology, it is perhaps a phenomenology that acknowledges the reality of the irreducible $<\ldots>$ and knows that it is impotent to bracket off (mettre hors jeu) the transcendent reality which it describes». I do not think there is any need to interpret Lacoste's formulation as necessarily referring to a «transcendent reality» proper - theological or otherwise. One may simply acknowledge the fact that in any experience, that which comes to our encounter is always experienced as something foreign to us: it is unexpected, inassimilable. These are precisely the features that make an experience an experience proper. In other words, to go through an experience means to experience something as irreducible, i.e., as something that resists the spontaneous tendency of consciousness to constantly re-establish the equilibrium between noesis and noema. In this sense, an experience can be described as an event-like encounter with the «real». ${ }^{6}$ On this basis, one may interpret

\footnotetext{
5 Phenomenology cannot prove anything in the deductive sense of the term (and even less confirm or falsify hypotheses as empirical sciences do). Cf. (Levinas, 1959). Certainly, there is room for rigorous arguments in phenomenological discourse: arguments, though, always necessarily presuppose the taking place of certain fundamental, pre-theoretical human experiences that constitute the phenomenological origin of phenomenological discourse.

${ }^{6}$ See (Tengelyi, 2006). In this book, Tengelyi proposes a phenomenological interpretation of experience in terms of an event suffered by consciousness - an event that consciousness could not master. Tengelyi characterizes experience as our encounter with a meaning that we had not prefigured or constituted a priori. This is why the emergence of the new can be described as an event. Drawing upon Husserl's distinction between Erlebnis and Erfahrung, Tengelyi writes that, «experience - in the sense of Erfahrung - often manifests itself in the form of a disappointment capable of refuting preconceived anticipations, denouncing established opinions, questioning prior convictions and resisting premeditated intentions» (Tengelyi, 2006, 14). Thus, Tengelyi conceives of experience as an event that precedes and surpasses consciousness. In this account, an event is an interruption of our power to giving meaning to things. Thus, there is a sense in which it can be said that reality is awakened in experience: «the idea of the formation (amorce) of meaning makes us understand how every experience, which is the place of the emergence of a new meaning, can be considered as an encounter and a contact with a reality independent of consciousness» (Tengelyi, 2006, 24).
} 
phenomenological reduction as the praxis of performing philosophical analysis while remaining attentive to those essential features of experience. Providing one bears in mind that the ultimate origin of experience is experience itself. It is the latter that promotes an attitude, or even a methodology, capable of not making violence to experience by imposing to it preconceived notions. Thus, when experience can show itself from itself, i.e., when it «speaks» in its own voice, the ontological status of its «contents» becomes «suspended» and reduction is effectively «performed». This is what may be called a «realistic' approach to experience.

What constitutes the irreducible in each kind of experience must be determined on a case-by-case basis. When it comes to ethical experience, what is revealed in it, presented in it as irreducible evidence, is ethical difference. Confronted with ethical difference, we find ourselves having to face the alternative of living according to the irreducibility of good to evil, or living «cynically» as if there was no difference whatsoever between good and evil. For most of us, though, the latter is not even an actual possibility: inasmuch as we are taken by ethical difference, we are not «free» to decide not to live our lives accordingly. These statements hold only at the most fundamental phenomenological level: it is when we are in the element of ethical experience that their truth is presented to us precisely as an «existential» or «ethical» impossibility — we cannot actually deny, in thought and action, the very existence of ethical difference.

We regularly experience ethical difference as being already determined. However, each manifestation of ethical difference is incapable of exhausting it. Not reducible to a concept, ethical difference is always given as a manifestation of meaning in the element of experience. It is in and by experience that it «delivers» its meaning. This is why a major difficulty all witnesses have to face when bearing witness to their experiences is their having to «re-actualize» in discourse something that belongs essentially to the reality of what had been lived and is still alive only in virtue of the workings of a traumatic memory. The witness is incapable of going back to his or her experiences as to verify somehow what she attests to in her discourse about them. At the very heart of testimony there is this essential or structural impossibility, this insurmountable limitation to conquer experience by means of a thematization of it. This is due to the intrinsically personal character of ethical experience, which cannot be integrated into a purely theoretical account of it.

A purely theoretical description of experience necessarily proceeds by forgetting that what is exposed to ethical difference is a person's subjectivity, understanding «person» as the «concrete character of man, considered in its flesh (chair), in its stories, i. e., in its relations» (Housset, 2007, 467). The witness never ceases to be a person; the person who bears witness never entirely becomes a theorizing subject. If it is true that every testimony counts, it is precisely because what was traumatically affected was not an abstract subject, but the concrete life of a person: his or her world constituted by meaningful relations and fundamental beliefs, expectations, and projects. Thus it should not be surprising that when it comes to elaborating the meaning of ethical experience, 
the witnesses - including, especially, those with strong intellectual and even philosophical inclinations - find in narrative discourse more suitable resources than in theory. Of course, this could hardly mean that narratives are devoid of understanding. ${ }^{7}$ What is at stake here, i.e., the crucial question that testimony brings to the fore, is how to elaborate the meaning of an experience in such a way that we remain somehow "faithful» to the truth that emerged in it. There can be no doubt that this is a phenomenologically relevant, and even urgent, question, especially when scientism - predominantly in the form of naturalistic-oriented as well as cognitive and neuroscientific approaches - has become a substantial component of the prevailing ideology in our time. ${ }^{8}$ As a consequence, it is experience itself that has become menaced. Indeed, scientific-oriented approaches reduce experience to what can be found out about «it» when examined through procedures that are ultimately foreign to it. It cannot be stressed enough that what is lost here is experience itself.

Although what is attested to in testimonies is the primal fact that there is ethical difference, the latter cannot be expressed in discourse but as a «theme» to be developed insistently as a series of variations. Following the musical analogy, it may be said that ethical difference organizes testimony as «silence» structures a musical piece from the inside out. ${ }^{9}$ Ethical difference, unable to manifest itself entirely in a particular statement, subtracts itself from any attempt to capture it. This is not a product of a limitation or deficiency that would be constitutive of language, but a positive trait of ethical difference itself. If the only way in which ethical difference could manifest itself in language was through a purely conceptual discourse, G.E. Moore would be right in recommending to submit oneself to the brutal simplicity of the tautology, «...good is good, and that is the end of the matter». ${ }^{10}$ Moore, however, makes here a two-fold mistake. First, neither «good» nor «evil» can be taken as isolated terms and, therefore, none of them is susceptible of being defined in an isolated manner. It is impossible to conceive one without

7 As Ricoeur puts it, a narrative involves «a sort of understanding $<\ldots>$ which is much closer to the practical wisdom of moral judgment than to science, or, more generally, to the theoretical use of reason» (Ricoeur, 1991, 23).

8 Michel Henry has presented a vigorous description of this state of affairs in his «La barbarie» (1987). Although I do not entirely agree with the phenomenological grounds of his view, it is an excellent point of departure to discuss this issue in full-length.

9 The «generative» power of silence in all domains of life has been examined by Max Picard in his «Die Welt des Schweigens» (1948). In «Quel che resta di Auschwitz» (1998), Giorgio Agamben presents the outlines of an ethics of testimony built on a careful examination of some testimonies of the survivors of the Shoah, where silence is at the basis of all bearing-witness and, in general, every speaking act: «Speaking is a paradoxical act that implies both subjectification and desubjectificacion, in which the living individual appropriates language only through a comprehensive expropriation, becoming a speaking being (parlante) only on the condition of falling into silence» (Agamben, 1998, 120).

${ }^{10}$ (Moore, 2000, § 6). 
the other. Second, it is not a question of defining ethical difference, but narrating one's exposition to it. This is precisely what testimonies do.

How does this encounter with ethical difference take place? I claimed that ethical difference is not a theoretical construct, but an actual given, a given that manifests itself to us in and as an experience. Moreover, ethical experience may be described as a «primal fact» in the sense that it is a contingent event that cannot be foreseen, mastered, or «produced» through a purely conceptual thematization of it. It is «primal» in that only this kind of event allows us to access to the ethical realm. This contingent character of experience is strictly linked to the fact that, as I claimed, the witness is not a subject, but a person: "Whereas the subject is that which posits itself as an I, the witness is born out of an encounter that is always fortuitous and somehow produced for and out of nothing» (Housset, 2007, 469). Indeed, as an in-itself, ethical difference is a pure difference, a «nothing». This is so only when we think about it in abstract terms. When we look at it as given in experience, though, what we find is that ethical difference is always given as an un-totalizable plurality of meanings, $i$. e., as a radically open series of expressions of the cleavage between good and evil as an irreducible polarity. We spontaneously find these expressions in our everyday life because our life is deeply rooted in them. These expressions of ethical difference are not fragments of a unified or total concept of «the Good». «The Good», taken as such, is a sheer abstraction. One way of making a legitimate use of this notion, though, consists in interpreting «Good» as the name for ethical difference in its factual plurality, a name, therefore, that does not refer to a totality, but to a multiplicity of events affecting us in concrete situations and contexts. Thus, it may be said that «the Good» manifests itself as the emergence of a plurality of «little goods»: ${ }^{11}$ if we think about it in this way, ethical difference as such has no content. What Løgstrup holds for what he calls «ethical demand» can be applied to ethical difference: «The demand gives no directions whatsoever about how the life of a person is to be served through word and action, but precisely which word and which action we must ourselves decide in each situation» (Løgstrup, 2007, 56).

The question we now have to address is how to positively «speak» about ethical difference so construed, i. e., how to build a philosophical discourse capable of inscribing in itself the contingency intrinsic to ethical experience. This question sends us back to the issue of the nature of testimony. In a nutshell: the inscription of the experience of ethical difference in ethical discourse can only take place in a philosophy that opens itself to the plurality of ethical testimonies, i. e., a philosophy informed by the kind of truth testimonies embody and convey, namely, ethical difference. ${ }^{12}$

${ }^{11}$ I take the expression «little goods» from Grossmann (2006).

${ }^{12}$ At first sight, testimony is just an example — surely an eminent one - of a «proto-philosophical» narrative capable of welcoming ethical difference in a way philosophical theorization cannot - other examples being theological, mythological, and filmic narratives. It remains an open question how each kind of narrative expresses ethical difference in its own way. 
Whereas an ethical theory neutralizes, annihilates the traumatic, contingent element of ethical experience, testimony not only welcomes ethical difference, but is born out of its demands and aims to remain faithful to it. What is truly at stake in the testimonies of Levi, Antelme, Semprún, and many others, is not an accurate description of actual events, but the attestation of ethical difference, i. e., an ethical-absolute that interrupts the course of a life as it necessarily develops itself in a particular historical context. Surely, reference to actual events is given in most testimonies; also, the witness certifies that certain historical events actually took place. However, the truth of testimony - ethical difference - transcends any given historical horizon. It is the dynamics of an actual encounter with ethical difference that must be narrated, which can surely be done even in an entirely «fictional» narrative. This is why a «false» testimony («false» in the sense that it deliberately depicts as «true» events that never took place) could ultimately still count as testimony. ${ }^{13}$

One can further elucidate the notion of a testimony's truth by studying the paragraphs of «Being and Time» where Heidegger analyzes the notion of «attestation» or «testimony» (Bezeugung). When examining those paragraphs ( $§ 54-60)$, one must pay careful attention to the context in which the discussion takes place. When a reader faces those paragraphs for the first time, it is likely that he will not be certain that the notion of Bezeugung actually corresponds to the phenomenon of testimony as characterized in the previous sections.

One of the most important lessons to learn from Heidegger's well-known analysis of das Man is that generally and for the most part we live our lives in the element of «impropriety» (Uneigentlichkeit). In particular, this means that ethics cannot start by postulating an alleged «rational» agent capable of taking autonomous decisions, but with the event of our subjectivity being reoriented by a «call» (Anruf) that sends us back to ourselves precisely because we have come to identify ourselves to the call's truth. Moreover, the call's truth is what allows us to identify ourselves to it: we have come to ourselves in virtue of our impossibility of denying the very reality of the call. Actually, it is in and through this impossibility that we can become ourselves. This holds regardless the ethical or non-ethical character of the call.

As I read it, Heidegger's analyses in these paragraphs describe the very dynamics of experience as such, i. e., experience proper. Thus, we go through an experience

\footnotetext{
${ }^{13}$ I have in mind the «Wilkomirsky case»: «In 1995 Binjamin Wilkomirski, a Swiss classical musician, published an account of a Polish Jewish childhood in the war. Translated into English the following year, it won literary prizes across the world and was praised for its bravery and authenticity in relating the child's experience of the Holocaust. It later emerged that Wilkomirski had, in fact, been adopted as a child and raised in a Swiss orphanage (becoming Bruno Dossekker from Bruce GrosJean)». Interestingly enough, some survivors of the Holocaust and, especially, child survivors groups, defended Wilkomirski's narrative as testimony (Kusher, 2006, 283).
} 
only when we are transfigured by the very emergence of Gewissen in the sense that we are «awakened» by the force and authority of the call's truth, which, in virtue of those features, becomes for us the very core of «reality». If it were not for the taking-place of this event, we would only live our lives in the element of impropriety, which would make all «decision» impossible, i. e., our lives could never be re-oriented in the direction of a truth.

The discussion of Bezeugung in «Being and Time» takes place in the context of Heidegger's analysis of the phenomenon of the voice of conscience (Stimme des Gewissens), i. e., that which opens for Dasein the very possibility of being itself in the form of «propriety». As well-known, for Heidegger the voice of conscience must be conceived as an ontological structure of Dasein. As a consequence, it is depicted as an original and ethically neutral transcendental structure that makes possible — and, on the properly phenomenological plane, precedes - any ethical interpretation of it. This is why it is inevitable that Heidegger's analyses seem quite abstract: in fact, the very content of the call has been suspended in order to focus on the general structure of the dynamics of all experience.

Heidegger claims that once it is called to itself by the voice of conscience, Dasein becomes able to attest itself in its propriety. It is crucial that the voice of conscience is interpreted as an ontological and not as an ontic phenomenon. When interpreted from an ontological perspective, one finds that conscience's «appeal» (Anruf) comes from Dasein itself. It is a call for Dasein to appropriate of its intrinsic possibility of questioning itself as a being lost in the anonymous neutrality of the «One» (das Man) and thus to (re)appropriate its innermost self (Heidegger, 1967, 272-273). By this appeal Dasein is called to «wake up» from the everyday slumber that keep it dispersed and fragmented in the domain of «One». This means concretely that it is only in virtue of its being called by conscience that Dasein can become free to chose - whatever it ends up choosing —, or, in a formulation closer to the original German, free for freedom (Heidegger, 1967, 268).

The structure of the appeal has three constituent moments to it. As I already suggested, when interpreted ethically these features have their counterpart in ethical difference as given in experience. However, the ethical interpretation of the appeal cannot be deduced from the ontological level. Moreover, between the ontological and the ethical level there is always a gap that cannot be bridged. The landmark of a rigorous ethics consists in its ability to situate itself in this gap ceaselessly shifting from ethics to ontology and back. The constituent moments of the appeal are as follows.

First, the origin and destination of the conscience's appeal coincide: both are Dasein in its innermost being. Second, the appeal has no descriptive content whatsoever: we are not informed by it about any state of affairs and cannot identify the appeal with any particular statement. In this sense, its realization is in the mode of silence, as if it were an intimation without words (Heidegger, 1967, 273). Third, the call has nonetheless a performative character to it: it allows Dasein to find itself and assert itself as a self that is no longer at the mercy of das Man. Two important additional observations: first, although 
this strange, indeterminate appeal comes from $u s$, it has an «authority» as if it came from above us (Der Ruf kommt aus mir und doch über mich) (Heidegger, 1967, 275). ${ }^{14}$ Second, for Heidegger, our understanding of the appeal is not a particular interpretation of the appeal, but the very form of a first and original freedom that makes possible for us to freely take any decision (Heidegger, 1967, 288). As a consequence, it is in virtue of the appeal that there can be responsibility at all, i. e., that we can be - and be held - responsible for our actions.

The previous essential features of Gewissen can and should be interpreted on a distinctively ethical plane. Such an interpretation is a condition for a full-fledged account of testimony as an elaboration of ethical experience construed as the actual givenness of ethical difference. On the basis of what was discussed in sections one and two, such an interpretation is relatively straightforward. To conclude, I will just outline its main points.

(1) Once ethical experience is interpreted in phenomenological terms, the question of the ultimate ontological status of that which is presented in ethical experience is suspended in the name of the intrinsic force and authority of the call itself. This is extremely important because it is methodologically crucial not to restrain the domain of a phenomenology of ethical experience to ethical encounters with human beings. From the very start, such a phenomenology must remain open to wherever the appeal comes from human or non-human «faces,» works of art, nature, future and past generations, and so on. Obviously, this is not to say that the appeal must be naively and unreflectively taken at face value; on the contrary, there must always be a strong, virtuous interaction between the ethical and the ontological level. From a phenomenological standpoint, though, it is hard to see why the origin of the call, in Heidegger's analysis, must be Dasein itself. Phenomenologically, what really counts is that the call is experienced as if it came «from above us». (2) In a sense, the appeal is «mute» in that no particular statement whatsoever can exhaust its meaning. This is precisely why testimonies, as the eminent expression(s) of singular experiences of radical evil, are — and must remain — multiple, i. e., irreducible to one another, and separate from a necessarily abstract «theory of evil». (3) The appeal re-orients our subjectivity in a direction of a truth whose meaning is never entirely revealed to us. It is a truth whose meaning we are compelled to interpret. Testimonies themselves are already interpretations of this truth, which is delivered to us through the witnesses in the form of particular interpretations that remain, in their turn, open to us. In this sense, one may speak of ethical difference not only as the «source» or «truth» of ethical experience, but as an event that reveals itself, in discourse, through testimonies. Ethical difference, though, remain absolute, inexhaustible. This is why each testimony is at the same time the expression of the ethical-absolute in its immediate character (each testimony is rooted in the manifestation of the absolute out of which it emerges) and already an interpretation, and therefore a singular instantiation, of this absolute.

\footnotetext{
${ }^{14} \mathrm{I}$ am interpreting this dimension of height that seems to be constitutive of the appeal as a dimension of authority - a term Heidegger does not use, but which seems to be clearly implied in his analyses.
} 


\section{REFERENCES}

Agamben, G. (1998). Quel che resta di Auschwitz. Torino: Bollati Boringhieri.

Améry, J. (1966). Jenseits von Schuld und Sühne. Bewältigungsversuche eines Überwältigen. München: Deutsche Taschenbuch.

Antelme, R. (1999). L'espèce humaine. Paris: Gallimard.

Curthoys, A., \& Docker, J. (2008). In D. Stone (Ed.), The Historiography of Genocide (9-41). New York: Palgrave Macmillan.

Derrida, J. (1996). Demeure. Fiction et témoignage. In M. Lisse (Ed.), Passions de la littérature. Avec Jacques Derrida (13-73). Paris: Galilée.

Derrida, J. (2005). Poétique et politique du témoignage. Paris: L'Herne.

Grossmann, V. (2006). Life and Destiny. New York: Review of Books.

Heidegger, M. (1967). Sein und Zeit. Tübingen: Max Niemeyer.

Henry, M. (1987). La Barbarie. Paris: PUF.

Housset, E. (2007). La vocation de la personne. L'histoire du concept de personne de sa naissance augustinienne à sa redécouverte phénoménologique. Paris: PUF.

Katz, S. (1994). The Holocaust in Historical Context. New York: Oxford University Press.

Kushner, T. (2006). Holocaust Testimony, Ethics, and the Problem of Representation. Poetics Today, 27 (2), 275-295.

Lacoste, J.-Y. (1998). La phénoménalité de Dieu. Neuf études. Paris: Les Éditions du Cerf.

Lanzmann, C. (Director). (1985). Shoah [DVD-Film]. France: Historia, Les Films Aleph, Ministère de la Culture de la Republique Française.

Levi, N., \& Rothberg, M. (Eds.). (2003). The Holocaust. Theoretical Readings. New Brunswick: Rutgers University Press.

Levene, M. (1988). Is the Holocaust Simply Another Example of Genocide? In S. Gigliotti, \& B. Lang (Eds.), The Holocaust. A Reader (420-447). Oxford: Blackwell Publishing.

Levene, M. (2005). Genocide in the Age of the Nation-State. Volume I: The Meaning of Genocide. New York: I. B.Tauris \& Co.

Levi, P. (1989). Se questo e un uomo. Torino: Einaudi.

Levi, P. (1991). Le sommersi e i salvati. Torino: Einaudi.

Levinas, E. (1959). Réflexions sur la technique phénoménologique. In Cahiers de Royaumont: Husserl (95-118). Paris: Les Éditions de Minuit. 
Levinas, E. (1972). Vérité du dévoilement, vérité du témoignage. In E. Castelli (Ed.), Le témoignage (101-110). Paris: Aubier.

Levinas, E. (1974). Autrement qu'être ou au-delà de l'essence. La Haye: Martinus Nijhoff.

Løgstrup, K. E. (1997). The Ethical Demand. Notre Dame: University of Notre Dame.

May, L. (2004). Genocide. A Normative Account. New York: Cambridge University Press.

Moore, G. E. (2000). Principia Ethica. Cambridge: Cambridge University Press.

Nabert, J. (1996). Le désir de Dieu. Paris: Les éditions du Cerf.

Picard, M. (1948). Die Welt des Schweigens. Erlenbach-Zürich-Konstanz: Rensch.

Rosenbaum, A. (2009). Is the Holocaust Unique? Perspectives on Comparative Genocide. Philadelphia: Westview Press.

Ricoeur, P. (1988). L'identité narrative. Esprit, 7-8, 295-314.

Ricoeur, P. (1991). Life in Quest of Narrative. In D. Wood (Ed.), On Paul Ricoeur. Narrative and Interpretation (20-33). London: Routledge.

Ricoeur, P. (1994a). Emmanuel Levinas, penseur du témoignage. In Lectures. Aux frontières de la philosophie (81-103). Paris: Seuil.

Ricoeur, P. (1994b). L'herméneutique du témoignage. In Lectures 3. Aux frontières de la philosophie (107-139). Paris: Seuil.

Ricoeur, P. (2000). L'histoire, la mémoire et l'oubli. Paris: Seuil.

Rousset, D. (1981). Les jours de notre mort. Paris: Fayard-Pluriel.

Rousset, D. (2010). L'univers concentrationnaire. Paris: Fayard-Pluriel.

Semprún, J. (1994). L'écriture ou la vie. Paris: Gallimard.

Tengelyi, L. (2006). L'expérience retrouvé. Essais philosophiques, I. Paris: Harmattan. 